This article investigates sex differences in the accuracy of young adults' retrospective reports of parental status using Joreskog's general framework for the simultaneous covariance structure analysis of multiple populations. Results indicate that young women's reports of maternal education are significantly more reliable than are young men's reports and that the reliabilities of reports of paternal traits are similar for young men and women.

\title{
Sex Differences
}

in Measurement Error

\section{in Status Attainment Models}

\author{
MARY CORCORAN
}

University of Michigan

\section{INTRODUCTION}

Empirical analyses of status attainment typically measure background by asking respondents to recollect their parents' or family's characteristics. If such retrospective reports are very unreliable, then this may bias parameter estimates (Bowles, 1972; Bowles and Nelson, 1974). A number of researchers have estimated response error models for men's retrospective reports of parental status (Bielby et al., 1977a, 1977b; Mason et al., 1976; Mare and Mason, in this issue) and several of these have estimated separate models of traits for different race or age-race groups. None examined measurement error patterns for women and only one study (Mare and Mason, this issue) has examined

\footnotetext{
AUTHOR'S NOTE: The research reported in this article was supported by the U.S. Department of Health, Education and Welfare and by National Science Foundation Grant SOC 7818535. This article has benefited from comments by Duane Alwin, Robert Ferber, Robert Hauser, Kent Jennings, Otis Dudley Duncan, Robert Mare, and two anonymous reviewers. The analysis strategy was developed by Mare and William M. Mason (in this issue) in their investigation of age differences in quality of boys' reports of parental status. None of the above institutions or individuals is responsible for any opinions or errors in this article.
} 
the pattern and strength of such relationships across populations as well as within populations. As Mare and Mason point out, estimating models across groups has two advantages: one can explicitly test for intergroup differences, and, by constraining particular parameters to be the same across groups, one can obtain more reliable parameter estimates.

A number of researchers have proposed and estimated models of women's status attainment and/or of differences in status attainment between men and women (Alexander and Eckland, 1974; Chase, 1975; Featherman and Hauser, 1976; McClendon, 1976; Rosenfeld, 1978; Treiman and Terrell, 1975a, 1975b; Tyree and Treas, 1974). But few, if any, have explicitly considered the possibility of measurement error in women's retrospective reports of parental status and / or sex differences in such measurement error.

At first glance, it seems unlikely that the quality of retrospective reports of parental traits will vary by sex. Yet, there are at least three plausible reasons to expect some variation by sex: sex differences in verbal contacts with parents, sex differences in expectations about the ways in which status is attained, and sex-role identification with the same-sex parent.

Gold berg and Lewis (1969) report that by as early as 13 months girls talk to their mothers more often than boys do. Unpublished data from Kent Jennings' longitudinal study of adolescent political socialization suggest that sex differences in verbal contact still exist in adolescence. These sex differences in verbal interactions with parents might improve girls' later recall relative to that of boys.

Some have argued that men's and women's mobility occurs through different channels - men attain status through individual achievement, while women derive status from kinship patterns. This assumption is implicit in the relative dearth of work, until quite recently, on women's status attainment. Even this recent work considers mobility through marriage as well as through individual achievement (Tyree and Treas, 1974; Glenn et al., 1974). If boys and girls have different expectations about status attainment, with girls expecting to derive status from kinship relationships with men, then the father's status may be more salient for young women. 
Third, children may take the same-sex parent as a role model (Rosenfeld, 1978). Thus, a father's characteristics may be more salient for boys and a mother's characteristics may be more salient for girls.

If the quality of retrospective reports of parental status varies by sex, this could systematically bias parameter estimates in structural equation models of sex differentials in the early statusattainment process. This could lead either to exaggerations or underestimations of the importance of sex differences in the status attainment process, depending on how the measurement error operates.

I will explore sex differences in retrospective reports of parental traits using a multiple group measurement model of young adults' reports of parental status similar to that employed by Mare and Mason. I will begin by estimating the extent and patterns of measurement error in women's and men's reports of their parents' status traits. As part of this estimate, I will test whether the structures of men's and women's measurement errors differ. Next, I will ask whether women's and men's retrospective reports of parental traits are less reliable than are their parents' contemporaneous reports of these traits. Finally, I will explore the extent to which corrections for measurement error alter estimates of sex differences in the educational attainment process.

$D A T A$

\section{SAMPLE}

The Panel Study of Income Dynamics (PSID) is a nationally representative longitudinal survey of 5000 American families. The Panel Study is well suited for an exploration of measurement error in retrospective reports, as it follows families over time and takes separate interviews with children who leave home.

The sample used here includes white, noninstitutionalized male household heads, female household heads and wives aged 23-30 in 1976 who were living with both parents in 1968. I chose this 
age range because the majority of children leave home by age 23 (Hill, 1977). This sample provides reports of:

(1) father's completed education, father's occupation in 1968, and mother's completed education in 1968 as reported by father in 1968

(2) mother's completed education as reported by mother in 1976

(3) father's completed education, father's usual occupation while respondent was growing up, and mother's completed education as reported by the respondent after the respondent had moved out of the 1968 parental household.

Respondents were dropped if they were missing data on any of these reports. The original sample included 280 white women and 316 white men. Of these, 222 women and 264 men had fathers who reported on their own education and occupation and on their wives' education and had mothers who reported their schooling in 1976. Finally, 208 women and 217 men reported on all 3 parental characteristics. ${ }^{1}$ Note that $6 \%$ (14 of 222$)$ of the women compared to $18 \%$ ( 47 of 264 ) of the men failed to report on all three parental traits.

\section{TIMING, WORDING AND CODING OF PARENTAL STATUS QUESTIONS}

The timing of questions about parents' traits differed by sex of offspring. Sons reported in the first interview year after they left home (or school). This means that sons could have left home any time from one day to eighteen months previously. ${ }^{3}$ Daughters, if married, reported in 1976. Daughters who headed their own households reported in the year that they became household heads. This means that daughters reported any time from one day to seven and one-half years after they left home (or school). Therefore, daughters, on the average, will have been out of the parental home longer than have sons when they report on parental traits. If recall diminishes over time, this might lower the reliability of daughters' reports relative to those of sons.

Questions about parental schooling differed somewhat for parents and offspring. Detailed, multiple-item protocols were 
used when fathers and mothers reported their own schooling and when fathers reported their wives' schooling; offspring were asked only two questions. Parents were asked, "How many grades of school did you finish?" while offspring were asked, "How much education did your father (or mother) have?" Coding procedures were quite similar for offspring and parents. ${ }^{4}$ It is unclear whether such differences in the number and wording of schooling questions would affect data quality, but I suspect that any such effects would operate to the parents' advantage.

The questions about father's occupation also differed slightly. Fathers were asked a question and a probe while offspring were asked a single question. Fathers were asked to report their "main occupation in 1968" (when offspring were 15 to 22 years old); offspring were asked, "What was your father's usual occupation while you were growing up?" Coding rules were the same for fathers and offspring. I used the Duncan score of father's occupation as a measure of the average occupational status of the father in the period during which children were growing up. Although the fathers' and children's questions do not apply to precisely the same time period, both questions give us a fix on the father's average occupational status. Indeed, one might argue that the offspring's question is more directly aimed at the desired characteristic.

\section{SAMPLE ADVANTAGES AND DISADVANTAGES}

The samples have advantages and disadvantages relative to other populations used in the analysis of measurement error. On the plus side, each has an extremely rich set of indicators of parental status. Both parents and children reported on parental characteristics. These reports were obtained at different times; the children were no longer living with their parents when they reported on parental traits; and the fathers described their own characteristics during a period when the children were still living at home. In addition, the sample sizes are large enough to estimate a fairly detailed model with some precision. Also, there are complete data on all the variables of interest.

On the other hand, the sample is restricted to young adults aged 15-22 in 1968 who were living in intact families in 1968 and 
who reported on their parents' traits within 8 years ( 1 day to 7-1/2 years) after leaving home. I suspect the quality of their retrospective reports should be as high or higher than that of adults in a wider age range or in a sample which includes children from broken homes. This sample should provide good upperbound estimates of reliabilities for retrospective reports of parental status.

There is also the problem that eliminating cases with missing data reduced sample sizes by about $30 \%$. This problem is compounded by the fact that sons were more likely than daughters to have missing data. If people with missing data on one question were more likely than other people to misreport on another question, then dropping missing data should raise the reliabilities of sons' reports relative to that of daughters' reports. However, most studies of measurement error have problems with missing data, and alternatives to excluding cases with missing data (e.g., use of pairwise correlations, assigning values) are equally limiting, as they often involve dubious assumptions and are likely to misrepresent the true structure (see Bielby et al., 1977a for an extensive discussion of this issue).

\section{STATISTICAL MODELS}

A SINGLE GROUP MEASUREMENT MODEL

For each sex, the basic measurement model can be described by the following seven algebraic equations:

$$
\begin{aligned}
& \mathrm{ED}_{\mathrm{f}-\mathrm{f}}=\lambda_{1 \mathrm{f}} \mathrm{ED}_{\mathrm{f}-\mathrm{t}}+\epsilon_{1 \mathrm{f}} \\
& \mathrm{ED}_{\mathrm{f}-\mathrm{o}}=\lambda_{10} \mathrm{ED}_{\mathrm{f}-\mathrm{t}}+\epsilon_{1 \mathrm{o}} \\
& \mathrm{OCC}_{\mathrm{f}-\mathrm{f}}=\lambda_{2 \mathrm{f}} \mathrm{OCC}_{\mathrm{f}-\mathrm{t}}+\epsilon_{2 \mathrm{f}} \\
& \mathrm{OCC}_{\mathrm{f}-\mathrm{o}}=\lambda_{20} \mathrm{OCC}_{\mathrm{f}-\mathrm{t}}+\epsilon_{2 o} \\
& \mathrm{ED}_{\mathrm{m}-\mathrm{f}}=\lambda_{3 \mathrm{f}} \mathrm{ED}_{\mathrm{m}-\mathrm{t}}+\epsilon_{3 \mathrm{f}}
\end{aligned}
$$




$$
\begin{aligned}
& \mathrm{ED}_{\mathrm{m}-\mathrm{o}}=\lambda_{30} \mathrm{ED}_{\mathrm{m}-\mathrm{t}}+\epsilon_{3 \mathrm{o}} \\
& \mathrm{ED}_{\mathrm{m}-\mathrm{m}}=\lambda_{3 \mathrm{~m}} \mathrm{ED}_{\mathrm{m}-\mathrm{t}}+\epsilon_{3 \mathrm{~m}}
\end{aligned}
$$

where:

$E D_{1^{-j}}=j^{\text {th }}$ person's report of the $i^{\text {th }}$ person's education; ${ }^{O C C_{i-j}}=$ the Duncan score of the $j^{\text {th }}$ person's report of the $i^{\text {th }}$ person's occupation; and $i, j=f$ for father, of for offspring, $\mathrm{m}$ for mother, and $\mathrm{t}$ for true.

This specifies that the $\mathrm{j}^{\text {th }}$ person's report of the $\mathrm{i}^{\text {th }}$ parental characteristic is equal to the true score of that characteristic multiplied by $\lambda_{\mathrm{ij}}$ plus a response error $\left(\epsilon_{\mathrm{ij}}\right)$ that is independent of the true score. To identify this model I set $\lambda_{1 \mathrm{f}}=\lambda_{2 \mathrm{f}}=\lambda_{3 \mathrm{~m}}=1$.

For each true parental status trait this is a congeneric model which allows for correlated errors (Jöreskog, 1969; Alwin and Jackson, forthcoming). In this model, true scores are allowed to covary; response errors are allowed to covary or are set at zero, depending upon hypotheses about measurement error. Parameter estimates can be used to calculate reliabilities (see Jöreskog, 1969).

One could examine sex differences in measurement error structures by estimating this model separately for sons and daughters, then comparing parameter estimates and reliabilities. However, this procedure does not permit a statistical test for sex differences in measurement error. Also, estimating models separately be sex produces two sets of parameter estimates for the covariances among true parental characteristics, as well as for the error variances of parental reports. This means that estimates of parental reliabilities will vary by sex of child. Because the accuracy of parents' reports probably does not vary with the sex of the child, it would be more efficient to combine information for both sexes to estimate a single set of true parental traits covariances and parental report reliabilities.

\section{MULTIPLE GROUP MEASUREMENT MODEL}

The shortcomings of the single group model approach can be handled by using Jöreskog's (1971) general framework for the 
simultaneous covariance structure analysis of multiple populations. In this framework, one can specify that the reliabilities of parents' reports and that the joint distribution of true parental characteristics are the same for sons and daughters, while allowing the measurement error structures and reliabilities of offspring's reports to vary by sex of offspring. ${ }^{5}$

Applying Jöreskog's model to equations 1 through 7 for young men and women gives a model of the form:

$$
\mathrm{Y}_{\mathrm{k}}=\Lambda_{\mathrm{k}} \mathrm{T}_{\mathrm{k}}+\epsilon_{\mathrm{k}}
$$

where:

$\mathrm{Y}_{\mathrm{k}}=7 \times 1$ vector of observed parental and offspring reports

$\mathrm{T}_{\mathrm{k}}=3 \times 1$ matrix of true scores

$\Lambda_{\mathrm{k}}=7 \times 3$ matrix of coefficients

$\epsilon_{\mathrm{k}}=7 \times 1$ vector of disturbance terms

and

$\mathrm{k}=\mathrm{s}$ for sons, $\mathrm{d}$ for daughters

This gives the following covariance matrix of observed reports:

$$
\epsilon\left(\mathrm{Y}_{\mathrm{k}} \mathrm{Y}_{\mathrm{k}}^{\prime}\right)=\Lambda_{\mathrm{k}} \Phi_{\mathrm{k}} \Lambda_{\mathrm{k}}^{\prime}+\Psi_{\mathrm{k}}
$$

where:

$$
\Phi_{\mathrm{k}}=3 \times 3 \text { covariance matrix of true scores }
$$

and

$$
\Psi_{k}=7 \times 7 \text { covariance matrix of error terms }
$$

In order to specify that the joint distribution of true parental status and the reliabilities of parents' reports do not vary by sex of offspring, I equated the true score covariance matrices for sons and daughters $\left(\Phi_{d}=\Phi_{s}\right)$ and equated error variances of the parents' reports of the parental characteristics for sons and daughters $\left(\Psi_{(11) \mathrm{s}}=\Psi_{(11) \mathrm{d}} ; \Psi_{(33) \mathrm{s}}=\Psi_{(33) \mathrm{d}} ; \Psi_{(55) \mathrm{s}}=\Psi_{(55) \mathrm{d}} ;\right.$ and $\Psi_{(77) \mathrm{s}}=$ 
$\left.\Psi_{(77) \mathrm{d}}\right) .^{6}$ In addition the slopes of the regressions of true mother's schooling on father's report of mother's schooling were equated for sons and daughters $\left(\lambda_{3 \text { fd }}=\lambda_{3 f s}\right)$.

\section{Specification of Error Covariances}

I investigated four alternative error patterns, as listed in Table 1:

(1) All measurement errors are random (Model I). Here all error covariances are set at zero. Thus $\Psi_{s}$ and $\Psi_{\mathrm{d}}$ are constrained to be diagonal.

(2) Offspring may guess at one parental status characteristic based on their knowledge of other parental status traits (Mason et al., 1976: 439-461). Offspring may overstate the consistency in parental status traits (Bielby et al.'s within-occasion, betweenvariable correlated error). This should result in correlations between the children's reporting errors. To test this, I allowed offspring's reporting errors to covary (Model II). The following covariances are estimated: $\Psi_{(24) \mathrm{d}} ; \Psi_{(26) \mathrm{d}} ; \Psi_{(46) \mathrm{d}} ; \Psi_{(24) \mathrm{s}} ; \Psi_{(26) \mathrm{s}} ; \Psi_{(46) \mathrm{s} \text {. }}$ Note this model might also pick up similarities in question sequences for 2 parental traits. For example, offspring's reports of mother's and father's schooling were elicited in response to similar sets of questions.

(3) Fathers may overstate the consistency between their own and their wives' status traits. This should result in correlations between fathers' reporting errors of their own and of their wives' schooling. To test this I estimated $\Psi_{(15) \mathrm{d}}$ and $\Psi_{(15) \mathrm{s}}$ (Model III). Because fathers' measurement error structures are constrained not to vary by sex of offspring, these two covariances a re equated.

(4) Finally, Models II and III are merged into a new model (Model IV) which allows offspring's reporting errors to covary and allows errors in fathers' reports of their own and of their wives' schooling to covary.

Other possible error patterns are less likely. Men might overstate the consistency in their own status characteristics so that the errors in fathers' reports of their schooling and education might covary. Bielby et al. (1977a, 1977b) investigated this type of nonrandom error in some detail and found no evidence of such error in their analysis of nonblacks. Offspring's and parents' 
reports of parental traits might covary but this seems unlikely, as reports are taken several years apart.

\section{TEST FOR SEX DIFFERENCES}

IN MEASUREMENT ERROR

Models I to IV allow the offspring's measurement error structures to vary by sex. After choosing the best-fitting model from Models I to IV, I tested for sex differences in measurement error structures by comparing that model to a model which frees the same error covariances as the best-fitting model, but which constrains male and female offspring's measurement error structures to be equal. If the constrained model does not provide a significantly worse fit to the data, then one can conclude that any observed sex differences in the quality of retrospective reports could have arisen from sampling variability.

\section{PROCEDURE FOR SELECTING A MODEL}

In addition to using goodness-of-fit statistics, I selected models by substantive plausibility (Mare and Mason, this issue). In particular, I specified that children's retrospective reports of parental status should be no more reliable than parents' selfreports. If parameter estimates implied that this was not so, then it was likely to be due either to a misspecified model or to sampling variability, and I reestimated the models using a specification which equates parents' and offspring's reliabilities. Similarly, it seemed reasonable to specify that mothers' reports of their own schooling should be at least as reliable as are fathers' reports of their wives' schooling.

Once I had chosen the best-fitting plausible model I investigated differences in estimated reliabilities between offspring and parents and between men and women. I did this by comparing models which equated slopes and error variances for particular 
groups (i.e., parallel measures models) to models which allowed these reliabilities to vary across groups. Whenever constraining reliabilities to be equal does not provide a significantly worse fit to the data, one cannot reject the hypothesis that the observed group differences in reliabilities could have arisen from sampling variability (see Mare and Mason, this issue).

\section{RESULTS}

\section{CHOICE OF A BEST-FITTING MODEL}

Table 1 reports the likelihood ratio-tests for Models I, II, III and IV when they are estimated using Jöreskog's general procedure for the simultaneous covariance structure analysis of multiple populations. These models are estimated with LISREL IV.

A comparision of Models I and II shows that allowing offspring's reporting errors of different parental traits to covary results in a chi-square of 14.94 (38.43-23.49) with 6 (33-27) degrees of freedom. This improvement in fit is statistically significant and suggests that offspring tend to make reports of parental status consistent with one another. Further allowing errors in fathers' reports of their own and their wives' schooling to covary (Model IV) results in a significant chi-square of 7.04 (23.49-16.45) with 1 degree of freedom. Apparently, men make reports of their own and their wives' schooling consistent with one another.

Model V constrains Model IV so that sons and daughters have identical measurement error structures. This is done by equating error variances, error covariance and slopes across sexes. Thus, $\Psi_{\mathrm{s}}=\Psi_{\mathrm{d}}$ and $\Lambda_{\mathrm{s}}=\Lambda_{\mathrm{d}}$. Model $\mathrm{V}$ provides a significantly worse fit ( $\chi^{2}=19.29$ with 9 degrees of freed om) to the data than does Model IV, suggesting that measurement error structures differ by sex.

Model IV provides the best fit among Models I through V. In Model IV, only 2 estimated covariances significantly differed from zero (using the .05 level): the covariances between errors in 
sons' reports of father's and of mother's schooling, and the covariances between errors in fathers' reports of father's and of mother's schooling. I simplified Model IV by setting all insignificant error covariances to zero. This new model (Model VI) did not provide a significantly worse fit to the data than did Model IV.

Under Model VI, the estimated reliabilities of daughters' reports of father's education (.837) and of father's occupation (.842) exceeded the estimated reliabilities of the fathers' own reports ( .815 and .832 , respectively). Also, the estimated reliabilities of fathers' and mothers' reports of mother's schooling were approximately equal (.902 vs. .892). I simplified Model VI by equating the reliabilities of daughters' and fathers' reports of father's schooling, of daughters' and fathers' reports of father's occupation, and of fathers' and mothers' reports of mothers' schooling (Model VII). Model VII did not provide a significantly worse fit to the data than did Model VI $\left(\chi^{2}=5.55\right.$ with 6 degrees of freedom). Thus, the apparently higher reliabilities of daughters' reports of father's schooling and occupation could be due to sampling error.

\section{PARAMETER ESTIMATES}

Table 2 lists the parameter estimates which obtain under Model VII. The estimated reliabilities of sons' retrospective reports of parental status were consistently lower than those for daughters' retrospective reports or those for parents' selfreports. This difference was largest for reports of mothers' education. The estimated reliabilities of daughters' reports of mothers' schooling were only slightly lower than those of pa rents' reports.

TESTS OF PARENT/CHILD

AND MALE/FEMALE DIFFERENCES

IN REPORT RELIABILITIES

As a last step, I tested whether these differences in reliabilities could be due to sampling variability. Model VIII constrains 


\section{TABLE 1}

Goodness-of-Fit Statistics for Measurement Models

(for noninstitutionalized, white household heads and wives, aged $23-30$ in 1976)

\begin{tabular}{|c|c|c|c|c|}
\hline Model & $x^{2}$ & & 8 of & $\begin{array}{l}\text { Probability } \\
\text { Level }\end{array}$ \\
\hline I. & Random measurement errors & 38.43 & 33 & .237 \\
\hline II. & $\begin{array}{l}\text { Covarlances atong all off- } \\
\text { spring's errors }\end{array}$ & 23.49 & 27 & .658 \\
\hline I I I . & $\begin{array}{l}\text { Covar fances awong errors in } \\
\text { fathers reports of their } \\
\text { own and their wives } \\
\text { schooling }\end{array}$ & 31.06 & 32 & .514 \\
\hline IV. & $\begin{array}{l}\text { Covarlances awong all off- } \\
\text { spring s errors and awong } \\
\text { errors in fathers reports } \\
\text { of their own and theit } \\
\text { wives schooling }\end{array}$ & 16.45 & 26 & .925 \\
\hline v. & $\begin{array}{l}\text { Model iv with oons and } \\
\text { daughters measurement error } \\
\text { structures constrained } \\
\text { to be equal }\end{array}$ & 35.64 & 35 & .438 \\
\hline VI. & $\begin{array}{l}\text { Covariances between errors in } \\
\text { reports of fathers education } \\
\text { and wothers education for both } \\
\text { sons and fathers }\end{array}$ & 20.35 & 31 & .928 \\
\hline VII. & $\begin{array}{l}\text { Model VI with the reliabllities } \\
\text { of daughters reports of fathers } \\
\text { ochooling, and fathers occupation } \\
\text { equated to the reliabllities } \\
\text { of fathers reports and wth the } \\
\text { rellabllities of fathers } \\
\text { and mothers reports of } \\
\text { mothers schooling equated }\end{array}$ & 26.80 & 37 & .892 \\
\hline VIII. & $\begin{array}{l}\text { Model VII with rellabilities } \\
\text { of parents and daughters } \\
\text { reports of mothers educa- } \\
\text { tlon equated }\end{array}$ & 28.68 & 39 & .888 \\
\hline$I X$. & $\begin{array}{l}\text { Model vill with rellabllities } \\
\text { of sons reports of fathers } \\
\text { occupation and of fathers } \\
\text { education constralned to } \\
\text { equal rellabllities of } \\
\text { fathers and of daughters } \\
\text { reports }\end{array}$ & 36.62 & 43 & .743 \\
\hline$x$. & $\begin{array}{l}\text { Model IX with reliabllitles } \\
\text { of sons reports of mothers } \\
\text { education constrained to } \\
\text { equal rellabllitles of } \\
\text { daughters and parents } \\
\text { reports }\end{array}$ & 60.27 & 45 & .064 \\
\hline
\end{tabular}


TABLE 2

Parameter Estimates, Model VII

\begin{tabular}{|c|c|c|c|c|c|}
\hline Characteristic & Reporter & $\begin{array}{c}\text { True Score } \\
\text { Variance }\end{array}$ & $\begin{array}{c}\text { Error } \\
\text { Variances }\end{array}$ & $\begin{array}{l}\text { Slopes } \\
\quad \text { (Standard } \\
\text { Errors are 1n } \\
\text { Parentheses) }\end{array}$ & Rellab111ty \\
\hline \multirow[t]{3}{*}{$\begin{array}{l}\text { Fathers' } \\
\text { schooling }\end{array}$} & Father & & 2.005 & 1.000 & .823 \\
\hline & Son & 9.349 & 2.796 & $\begin{array}{c}.933 \\
(.050)\end{array}$ & .744 \\
\hline & Daughter & & 2.005 & 1.000 & .823 \\
\hline \multirow[t]{3}{*}{$\begin{array}{l}\text { Fathers } \\
\text { occupat } 1 \text { on }\end{array}$} & Father & & 66.8 & 1.000 & .837 \\
\hline & Son & 343.8 & 88.4 & $\begin{array}{c}.902 \\
(.048)\end{array}$ & .760 \\
\hline & Daughter & & 66.8 & 1.000 & .837 \\
\hline \multirow[t]{4}{*}{$\begin{array}{l}\text { Mothers } \\
\text { schooling }\end{array}$} & Father & & .834 & 1.000 & .894 \\
\hline & Son & 7.015 & 1.778 & $\begin{array}{c}.927 \\
(.038)\end{array}$ & .772 \\
\hline & Daughter & & 1.044 & $\begin{array}{l}.980 \\
(.033)\end{array}$ & .866 \\
\hline & Mother & & .834 & 1.000 & .894 \\
\hline \multicolumn{6}{|c|}{$\begin{array}{c}\text { Error Covariances and Correlations Between Errors in } \\
\text { Reports of Mother }{ }^{-1} \text { and Father's Schooling } \\
\text { Covarlance Correlation }\end{array}$} \\
\hline $\begin{array}{l}\text { Sons } \\
\text { Fathers }\end{array}$ & & $\begin{array}{l}.544 \\
.272\end{array}$ & $\begin{array}{l}.244 \\
.210\end{array}$ & & \\
\hline
\end{tabular}

parents and daughters to be equally reliable when reporting mother's schooling. Model VIII does not provide a significantly worse fit to the data than does Model VII. Young women's retrospective reports of parental status appear to be as reliable as are parents' self-reports. When we further constrain our model so that the reliabilities of reports of father's schooling are equated for fathers and sons (and thus, for sons and daughters) the new 
TABLE 3

Parameter Estimates, Model IX

\begin{tabular}{|c|c|c|c|c|c|}
\hline Characterist 1c & Reporter & $\begin{array}{c}\text { True Score } \\
\text { Varlance }\end{array}$ & $\begin{array}{c}\text { Error } \\
\text { Var1ances }\end{array}$ & $\begin{array}{l}\text { Slopes } \\
\text { (Standard } \\
\text { Errors are in } \\
\text { Parentheses) }\end{array}$ & Re11ab111ty \\
\hline $\begin{array}{l}\text { Fathers } \\
\text { schooling }\end{array}$ & $\begin{array}{l}\text { Father } \\
\text { Son } \\
\text { Daughter }\end{array}$ & 9.004 & $\begin{array}{l}2.230 \\
2.230 \\
2.130\end{array}$ & $\begin{array}{l}1.000 \\
1.000 \\
1.000\end{array}$ & $\begin{array}{l}.801 \\
.801 \\
.801\end{array}$ \\
\hline $\begin{array}{l}\text { Fathers' } \\
\text { occupation }\end{array}$ & $\begin{array}{l}\text { Father } \\
\text { Son } \\
\text { Daughter }\end{array}$ & 326.1 & $\begin{array}{l}73.2 \\
73.2 \\
73.2\end{array}$ & $\begin{array}{l}1.000 \\
1.000 \\
1.000\end{array}$ & $\begin{array}{l}.817 \\
.817 \\
.817\end{array}$ \\
\hline $\begin{array}{l}\text { Mothers } \\
\text { schoollng }\end{array}$ & $\begin{array}{l}\text { Father } \\
\text { Son } \\
\text { Daughter } \\
\text { Mother }\end{array}$ & 6.946 & $\begin{array}{r}.884 \\
1.740 \\
.884 \\
.884\end{array}$ & $\begin{array}{l}1.000 \\
.939 \\
(.038) \\
1.000 \\
1.000\end{array}$ & $\begin{array}{l}.887 \\
.779 \\
.887 \\
.887\end{array}$ \\
\hline $\begin{array}{r}\text { Error Co } \\
\text { Repo }\end{array}$ & $\begin{array}{l}\text { variances } \\
\text { rts of Mot } \\
\text { Cov }\end{array}$ & $\begin{array}{l}\text { and Correla } \\
\text { her's and } F \\
\text { gariance Co }\end{array}$ & $\begin{array}{l}\text { ations Bet } \\
\text { Father }{ }^{-} \mathrm{S} \\
\text { orrelation }\end{array}$ & $\begin{array}{l}\text { ween Errors in } \\
\text { chooling }\end{array}$ & \\
\hline $\begin{array}{l}\text { Sons } \\
\text { Fathers }\end{array}$ & & $\begin{array}{l}.453 \\
.301\end{array}$ & $\begin{array}{l}.230 \\
.215\end{array}$ & & \\
\hline
\end{tabular}

model (Model IX) preserves a satisfactory fit to the data. Thus, the observed lower reliabilities of sons might be due to sampling variability. Finally, Model X equates the reliabilities of sons' and parents' reports of mother's schooling. Model X provides a significantly worse fit to the data than does Model IX. Sons' reports of mother's schooling are less reliable than are the reports of mothers, fathers, or daughters. Table 3 presents the parameter estimates which obtain under Model IX.

\section{EFFECTS OF MEASUREMENT ERROR ON} ESTIMATES OF SEX DIFFERENCES

IN THE EDUCATIONAL ATTAINMENT PROCESS

Table 4 presents the regressions of the parental status measures on offspring's education. Estimates are derived given three dif- 
TABLE 4

Regressions Uncorrected and Corrected for Measurement Error (dependent variable $=$ years of schooling)

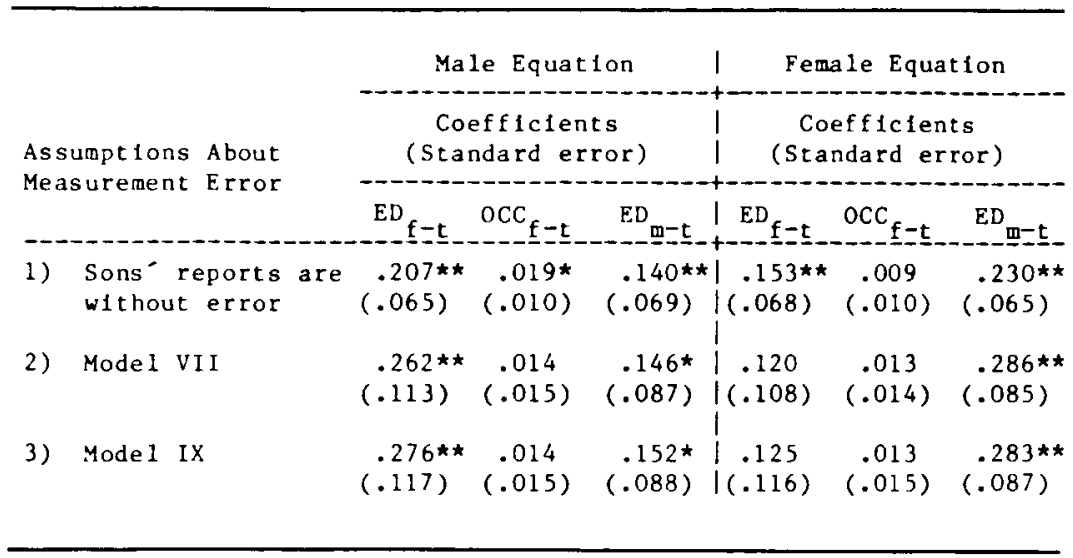

ferent assumptions about the measurement error structure: (1) offspring's reports are without error; (2) Model VII is correct; and (3) Model IX is correct. Corrected estimates are obtained by specifying the measurement structure of Model VII (or IX) and simultaneously estimating measurement and structural parameters (Bielby et al., 1977a, 1977b). Results obtained under the assumption that offspring's reports are without error are similar for men and women, but there is very weak evidence that the education of the same-sex parent has more effect than that of the other parent on young adults' level of schooling. Previous studies of status attainment (Treiman and Terrell, 1975a; Featherman and Hauser, 1976) have also reported weak evidence of modeling on the same-sex parent.

When corrections are made for measurement error, parameter estimates change slightly within equations, and the suggestive evidence of identification with the same-sex parent is strengthened. The impact of an additional year of parental schooling on offspring's schooling is larger by a factor of two when the parent and offspring are the same sex. Note, however, that corrections for measurement error have only modest effects within individual equations. 


\section{SUMMARY}

Young women's retrospective reports of parental status seem as accurate as parents' own reports. In only one instance, mother's education, was the estimated reliability of women's reports lower than that of parents, and this was not significant. Also, there is no evidence to suggest that there are nonrandom errors in young women's retrospective reports.

The estimated reliabilities of young men's retrospective reports of father's education and father's occupation were consistently lower than the estimated reliabilities of parents' self-reports, but these differences were not significant. This is consistent with Bielby et al.'s (1977a, 1977b) result that contemporaneous reports of men's status were as reliable as were retrospective reports of father's education and father's occupation.

Young men's retrospective reports of mother's schooling were significantly less reliable than were fathers' reports or mothers' reports. This suggest that the quality of men's retrospective reports of maternal traits may be poor and that the mother's status has relatively low salience for sons. In addition, errors in sons' reports of mothers' and fathers' schooling were correlated $(r=.23)$, suggesting that young men use one parent's schooling to guess about the schooling of the other parent. (Note that if this correlation were due to similarities in questions or coding, then it is surprising that it did not show up for daughters.)

Estimated reliabilities for reports of father's traits were always higher for young women than for young men, but these differences were not significant. Thus these data provide weak, if any, evidence to support the hypotheses that sex differences in verbal contacts and/or in the ways that status is attained improve women's relative ability to recollect paternal traits.

There is persuasive evidence that young women report maternal status more accurately than do young men. Sons' retrospective reports of a mother's schooling were considerably less reliable than were daughters' retrospective reports. Further, there was no evidence of nonrandom error in daughters' reports of parental traits, but the errors in sons' reports of their mothers' and fathers' schooling were correlated. This supports the hy- 
pothesis that maternal status is more salient for women than for men.

It may be useful to compare the magnitude of these sex differences in measurement error structure with other estimates of intergroup differences. For example, these differences a re similar in magnitude to those reported by Mare and Mason for ninthand twelfth-grade boys, but they are much smaller than the race differences reported by Bielby et al. (1977a).

Finally, there is suggestive but far from conclusive evidence that not correcting for measurement error may underestimate the extent of sex-role modeling on the same-sex parent in the schooling process. This suggests that it may be important that future researchers consider the possibility that failure to correct for measurement error may reduce estimates of sex differences in the status attainment process.

\section{NOTES}

1. These restrictions had trivial effects on the means and variances of these parental characteristics. Those interested can obtain tables from the author.

2. I am grateful to Professor R. Hauser (1979) for pointing out that these differences might affect reliabilities. The following discussion borrows heavily from points raised by Hauser. Those interested in the exact wording of questions or coding procedures can obtain these from the author.

3. There is one exception. Sons reported on their mothers' schooling in 1974 if they left home prior to 1974.

4. Again, there is an exception. "Don't know" responses were coded differently for parents and offspring. I dealt with this by looking up all such cases for offspring and recoding them using the parents' coding rules.

5. This is similar to the strategy employed by Mare and Mason (this issue).

6. This follows Mare and Mason's strategy.

7. Both Mare and Mason (this issue) and Hauser (1979) suggest this possibility.

\section{REFERENCES}

ALEXANDER, K. L. and B. K. ECKLAND (1974) "Sex differences in the educational attainment process." Amer. Soc. Rev. 39 (October): 668-682.

ALWIN, D. F. and D. J. JACKSON (forthcoming) “Applications of simultaneous factor analysis to issues of factor invariance," in D. J. Jackson and E. F. Borgatta (eds.) Factor Analysis and Measurement in Sociological Research. Beverly Hills, CA: Sage. 
BIELBY, W. T., R. M. HAUSER, and D. L. FEATHER MAN (1977a) "Response errors of black and nonblack males in models of the intergenerational transmission of socioeconomic status." Amer. J. of Sociology 82 (May): 1242-1288.

___ (1977b) "Response errors of nonblack males in models of the stratification process." J. of the Amer. Stat. Assn. 72 (December): 723-735.

BOWLES, S. (1972) "Schooling and inequality from generation to generation." J. of Pol. Economy (May/June): S219-S251.

_—_ and V. NELSON (1974) "The 'inheritance of IQ' and the intergenerational reproduction of economic inequality." Rev. of Economics and Statistics 56: 39-51.

CHASE, I. (1975) "A comparison of men's and women's intergenerational mobility in the United States." Amer. Soc. Rev. 40 (August): 483-505.

FEATHERMAN, D. L. and R. M. HAUSER (1976) "Sexual inequalities and socioeconomic achievement in the U.S.: 1962-1973." Amer. Soc. Rev. 41 (June): 462-483.

GLENN, N. D., A. A. ROSS, and J. C. TULLY (1974) "Patterns of intergenerational mobility of women through marriage." Amer. Soc. Rev. 39 (October): 683-699.

GOLDBERG, S. and M. LEWIS (1969) "Play behavior in the year-old infant: early sex differences." Child Development 40 (March): 21-30.

HAUSER, R. M. (1979) Personal communication.

HILL, M. S. (1977) "The decision by young adults to split off from their parents' household." Ph.D. dissertation, University of Michigan.

JORESKOG, K. G. (1971) "Simultaneous factor analysis in several populations." Psychometrika 26 (September): 409-426.

-__ (1969) “A general approach to confirmatory maximum likelihood factor analysis." Psychometrika 34 (June): 183-202.

- - and D. SORBOM (1978) LISREL IV: Analysis of Linear Structural Relationships by the Method of Maximum Likelihood. Chicago: National Educational Resources.

MASON, W. M., R. M. HAUSER, A. C. KERCK HOFF, S.S. POSS, and K. MANTON (1976) "Models of response error in student reports of parental socioeconmic characteristics," pp. 443-494 in W. H. Sewell et al. (eds.) Schooling and Achievement in American Society. New York: Academic.

McCLENDON, M. (1976) "The occupational status attainment processes of males and females." Amer. Soc. Rev. 41 (February): 52-64.

ROSENFELD, R. (1978) "Women's intergenerational occupational mobility." Amer. Soc. Rev. 43 (February): 36-46.

TREIMAN, D. J. and K. TERRELL (1975a) "Sex and the process of status attainment: a comparison of working women and men." Amer. Soc. Rev. 40 (April): 174-200.

-__ (1975b) "Women, work, and wages-trends in the female occupational structure," in K. C. Land and S. Spilerman (eds.) Social Indicator Models. New York: Russell Sage.

TYREE, A. and J. TREAS (1974) "The occupational and marital mobility of women." Anier. Soc. Rev. 39 (June): 293-302.

Mary Corcoran is an assistant professor of political science and a stud!' director at the Institute for Social Research at University of Michigan. Her current work is in the areas of sex discrimination, social stratification and unemplolment. She is a coauthor of Who Gets Ahead (Basic Books, 1979). 